\title{
THE ORGANIZATIONAL VALORIZATION OF EMPLOYEES WHO ARE SATISFIED WITH THEIR LIVE
}

\author{
Bernard Gangloff ${ }^{1}, \&$ Neila Malleh $^{2}$ \\ ${ }^{1}$ Laboratoire Parisien de Psychologie Sociale, Université Paris 10 (France) \\ ${ }^{2}$ Institut Supérieur de l'Animation pour la Jeunesse et la Culture, Université de Tunis (Tunisia)
}

\begin{abstract}
Satisfaction with life seems to have many positive aspects. Our general hypothesis is that employees who feel satisfaction with life will be positively valued by their superiors, and that this positive value, which evokes the concept of social norms, allows us to assign to satisfaction with life a normative status. Three populations (128 line managers, 176 students destined to become human resource managers, and 307 employees) responded to a satisfaction with life questionnaire. Managers had to indicate, for each item, if they appreciated (or not) an employee feeling the satisfaction presented in the item; students had to indicate which items an employee should check if s/he wants to be positively (versus negatively) appreciated by his/her superior; and employees had to indicate if each item corresponded to the satisfaction they used to feel. Three hypotheses are developed and confirmed: managers positively value employees feeling satisfaction with life; students are aware of this positivity; spontaneously employees show satisfaction with life, which means, knowing that spontaneous self-presentation is often produced by social desirability, that employees are aware of the satisfaction positivity. These data are discussed under a conceptual and applied angle.
\end{abstract}

Keywords: Satisfaction with life, organizational normativity.

\section{Introduction}

Numerous theories on satisfaction have been formulated so far (Diener et al., 1999). Bouffard (1997) has proposed a classification that differentiates the general theories from the so-called specific ones. The former can be divided into two groups. The ascending theories (including the works of Diener, Sandvik, Pavot \& Gallagher, 1991; Okun, Olding \& Cohn, 1990; Cohen, Towbes \& Flocco, 1988), suggest that satisfaction comes from the aggregation of all micro-satisfactions resulted from various areas of life (such as familial, professional, conjugal, friendly). The descending theories (Lykken \& Tellegen, 1996; McCrae \& Costa, 1991; Seligman, 1991) propose a reversed order: the existence of a personality structure that predisposes to satisfaction or dissatisfaction and influences the interpretation of life events in terms of satisfaction or dissatisfaction. In what regards the specific theories, meant to complement the general theories, they particularly include the cognitive theories (which examine the manner in which the cognitive operations transform the objective information into subjective data : e.g. Lent et al., 2005; Ryff \& Essex, 1992; Weiner, 1992); the theory of standards (according to which the satisfaction in life comes from evaluating the distance that separates us from a standard, the latter being generally other people: Buunk, Collins, Taylor, Van Yperen \& Dakof, 1990; Easterlin, 1995; Emmons \& Diener, 1985; Frieswijk, Buunk, Steverink \& Slaets, 2004; Pelham et Wachsmuth, 1995); or the theory of goals, which is based on intrapersonal comparisons that relate aspirations and their achievement (such as Oishi et al., 1999; Ryan \& Deci, 2000; Spence, Oades \& Caputi, 2004).

However, these different points of view do not hinder a consensual definition of satisfaction. Andrews \& Withey (1976) point out that life satisfaction corresponds to one of three components of subjective wellbeing characterised, alongside two emotional components (positive and negative emotions: see Bradburn, 1969), by a cognitive and evaluative component. The feeling of satisfaction, according to Mercier \& Filion (1987, p. 137), entails in fact a judgement, an evaluation. Life satisfaction is thus defined as «a global evaluation of a person's life quality, according to their own criteria" (Shin \& Johnson, 1978, p.478). 
In the professional field, numerous studies have highlighted the fact that work satisfaction has a positive effect on several areas: performance (Aziri, 2011; Javed, Balouch \& Hassan, 2014; Lai Wan, 2007; Nanda \& Browne (1977)), organisational commitment and loyalty (Chen, 2006; Fletcher \& Williams, 1996; Javed et al. 2014; Martensen \& Gronholdt, 2001; Vanderberg \& Lance, 1992), attachment to the company and desire to remain in it (Chen, 2006; Muchinsky \& Morrow, 1980), etc. Certain authors considered that such positive consequences could also be derived from the individuals' evaluation of their life as a whole (and not only of their satisfaction within the professional area), leading to the company managers valuing the employees who evaluate their life as a whole in a positive manner. Such is the case of the study conducted by Gangloff and Malleh (2016). But these authors have used a multidimensional scale (the Psychological Wellbeing Manifestation Scale of Massé et al., 1998), which refers to different strata of life (need of self-esteem, of sociability, self-control and events, etc.). Due to the fact that the appreciation criteria for life quality vary according to individuals, Diener, Emmons, Larsen \& Griffin (1985, p. 71) find it more pertinent to examine people's global satisfaction than to interrogate them regarding their satisfaction in one field or another, or in one stratum or another and then sum it up. Therefore, we wanted to resume the idea of Gangloff and Malleh, but by applying a global scale. More specifically, we wanted to test the hypothesis according to which satisfaction meets certain characteristics of a social norm.

The term "norm" refers to «that which seems desirable, suitable within a specific society or group» (Maisonneuve, 1973, p.59). Dubois also writes $(1994$, p.28) that «a norm defines a set of events judged as being good or desirable by the collective from which they emerge, as opposed to another set of events regarded as being less good or less desirable, even frankly bad». Dubois (1994, p.28-29) states that all norms result from social learning (which means that the propagation and integration of norms vary according to social groups) and are based on an informal value allocation (this value being related to the utility and/or the desirability attributed to the norm within the framework of social functioning: Dubois, 2005). This article aims to show that life satisfaction meets certain aspects of this definition and could therefore be attributed the first constituent elements of a normative status. Therefore, we formulate the following operational hypotheses:

- executives value employees who report a high level of satisfaction (H1),

- non-executives are aware of this valuation and they usually have a high level of satisfaction $(\mathrm{H} 2)$,

- non-executives are aware of this valuation and, in order to give a good image of themselves, they declare to have a high level of satisfaction (H3).

\section{Method}

Gosselin (2005) has classified the measurement tools for investigating life satisfaction into two categories: global instruments (which allow the measuring of satisfaction within an integrative spirit, e.g. the scale of Diener et al., 1985), and the instruments measuring various facets of satisfaction corresponding to different areas of life (work, family, personal relations, leisure) or to different strata of life. We have emphasized the criticism brought by Diener et al. (1985) against faceted scales. Moreover, Diener (1984) remarks that the global satisfaction scales often contain only one item, or still yet, are meant for specific populations (particularly elderly people), or even relate to aspects not inherent to satisfaction. Excluding such instruments, we have used ten items (five of satisfaction and five of dissatisfaction ${ }^{1}$ ), two of which were extracted directly from the SWLS by Diener et al. (1985), seven were developed starting from that same scale, and a tenth were derived from Huebner's students' life satisfaction scale (SLSS) (1991). We asked three populations (two populations of employees - executives and non-executives, and one population of students) to respond individually and voluntarily to that scale, and we obtained a satisfactory Cronbach alpha (.738).

The population of executives ( $\mathrm{N}=128$ men) was subjected to the legislator's paradigm (Gangloff, 2008). Those executives were thus instructed to indicate, for each item, if they would appreciate (or not) if an employee adopted the behaviour presented in the item. The respondents thus checked each item according to a dichotomous principle: appreciated response versus rejected response. The non-executive employees ( $\mathrm{N}=307$ men) were confronted with the self-presentation paradigm with neutral instructions, meaning they had to indicate, in all sincerity, on a 4-point scale (true, rather true, rather false, false), the degree to which each sentence corresponded to a conduct they normally adopted. Finally, the students ( $\mathrm{N}=176$ : 134 women and 42 men) were confronted to a new paradigm, created for this occasion: the

\footnotetext{
${ }^{1}$ 1) So far, I've obtained the important things that I wanted from life (extracted from the SWLS scale), 2) So far, I've not obtained much of what I wanted in my life, 3) I often envy the lives of others, 4) I have a life that is more satisfying than that of many others, 5) When I am not satisfied with something, all the other areas of my life are affected ,6) It suffices for everything to go well in one area, for me to feel satisfied, 7) So far, I am satisfied with the choices I've made in my life, 8) If I could, I would change many of the decisions I've made during my life, 9) I am satisfied with my life (extracted from the SWLS scale), 10) I would love to change many things in my life (extracted from SLSS).
} 
paradigm of «courtesan self-presentation»: the participants were confronted with the following instructions: «You were asked to respond to the following questionnaire by imagining the answers that an employee should check in order to be appreciated by their superior, and which should they check if they wanted to be badly regarded by their superior». The respondents thus checked each item according to a dichotomous principle: in order to be well regarded versus in order to be badly regarded ${ }^{2}$.

\section{Results}

\subsection{For executives $(\mathrm{N}=128)$}

We notice (Table 1 ) that the positive answers are significantly more frequent than the negative ones $\left(\chi^{2}=455,88 ; p \approx .00\right)$.

Table 1. Distribution of executive employees' answers in raw data (and \% between parenthese.) NB: due to 3 non-answers, the total is less than 1280 (128 participants $x 10$ items).

\begin{tabular}{cc}
\hline Positive answers & $1020(79.87 \%)$ \\
\hline Negative answers & $257(20.13 \%)$ \\
\hline Total & $1277(100 \%)$ \\
\hline
\end{tabular}

\subsection{For non-executives $(\mathbf{N}=307)$}

Here once more (Table 2), the positive answers are more frequent than the negative ones $\left(\chi^{2}=504,10 ; p \approx .00\right)$. It should however be noted that the executives provided more positive answers than the non-executives $\left(\chi^{2}=42,07 ; p \approx .00\right)$.

Table 2. Distribution of non-executive employees' answers in raw data (and \% between parentheses). NB: due to 10 non-answers, the total is less than 3070 (307 participants $x 10$ items).

\begin{tabular}{cc}
\hline Positive answers & $2151(70.29 \%)$ \\
\hline Negative answers & $909(29.71 \%)$ \\
\hline Total & $3060(100 \%)$ \\
\hline
\end{tabular}

3.3. For students $(\mathrm{N}=176$ : 134 women and 42 men)

Taken globally (i.e. for both men and women), the positive answers are more frequent than the negative answers (Table $3 ; \chi^{2}=966.75 ; p \approx .00$ ), which is also observed for women (Table 3: $\chi^{2}=682.33$; $p \approx .00$ ) and for men (Table $3 ; \chi^{2}=288.62 ; p \approx .00$ ). However, men provide more positive answers than women $\left(\chi^{2}=9.65 ; p=.001\right)$.

Moreover, we notice that the students systematically provide more positive answers than the executives, both men and women together $\left(\chi^{2}=32,35 ; p \approx .00\right)$ and men $\left(\chi^{2}=31,79 ; p \approx .00\right)$ or women $\left(\chi^{2}=18,00 ; p \approx .00\right)$ taken individually. Similarly, the students' answers are more frequently positive than those of the non-executive employees, both for men and women together $\left(\chi^{2}=181,59 ; p \approx .00\right)$ and for men $\left(\chi^{2}=85,74 ; p \approx .00\right)$ or women $\left(\chi^{2}=122,70 ; p \approx .00\right)$ taken individually.

Table 3. Distribution of the students' answers, in raw data (and \% between parentheses). NB: For men and women combined, due to 44 non-responses, the total is below 1760 (176 participants $x 10$ items). For women, due to 34 non-responses, the total is below 1340 (134 participants $x 10$ items). For men, due to 10 non-responses, the total is below 420 (42 participants $x 10$ items).

\begin{tabular}{cccc}
\hline & Men + Women & Men & Women \\
\hline Positive answers & $1502(87.53 \%)$ & $1125(86.14 \%)$ & $377(91.95 \%)$ \\
\hline Negative answers & $214(12.47 \%)$ & $181(13.86 \%)$ & $33(8.05 \%)$ \\
\hline Total & $1716(100 \%)$ & $1306(100 \%)$ & $410(100 \%)$ \\
\hline
\end{tabular}

\footnotetext{
2 The self-presentation paradigm is usually of three types (acc. to Jellison \& Green, 1981): 1) self-presentation with neutral or standard instructions (answer the questionnaire as sincerely as possible); 2) with self-valuation instructions (answer trying to render the best self-image possible); 3) with self-devaluation instructions (answer trying to render the worst self-image possible). Usually, the self-valuation and self-devaluation instructions are used together: the difference in answers obtained between the two sets of instructions is considered to emphasize the perception of respondents in what regards the difference in social value awarded to one or the other type of answers. But this combined usage seems methodologically problematical, whether carried out intra-subjectively (each respondent answers successively according to the set of instructions received, which leads to a potential halo effect which can only be compensated by controlling the order effect) or inter-subjectively (in this case, the inter-subjective differences could bias the results). The method we have chosen (the courtesan self-presentation paradigm) allows us to avoid each of those two pitfalls.
} 


\section{Discussion-Conclusion}

We hypothesized that satisfaction would meet the main criteria characterising a social norm. Our results indicate that this is indeed the case: the executives claim to value the employees who report high satisfaction (hypothesis 1). In addition, we observe that declaring such an elevated feeling is effective for non-executive employees (hypothesis 2), which could mean, if we take into consideration the fact that the self-presentation paradigm with neutral instructions frequently produces answers impregnated with social desirability, a clairvoyance of the employees in terms of such valuation: the latter would declare themselves to be satisfied because they would have integrated the fact that such statement of satisfaction is valued. Finally, this clairvoyance is more directly confirmed on our third population by the fact that the future employees, in this case, the students, are indeed aware of this valuation and report a higher satisfaction in order to demonstrate their worth and, a contrario, they display a weaker satisfaction in order to render a bad image of themselves (hypothesis 3). Finally, we observe that the executives provide more positive answers than the non-executives, and that the students provide more positive answers than executive employees and non-executive employees.

One of the limitations of this study is having considered the status of our three populations to be their sole descriptive criterion (employees or students). However, the results obtained, far from being inconsistent, respond well to the hypotheses formulated. The mutations faced by organisations, particularly as a result of globalisation and the competition it induces, leads them to extend their exigencies in terms of individual performance and flexibility. The competences sought are indeed more and more frequently related to adaptability. The studies conducted by Pulakos (e.g. Pulakos, Schmitt, Dorsey, Hedge \& Borman, 2002) on adaptive performance (which translate the individuals' capacity to adapt to the new exigencies of a job), underline the fact that such performance is supported by an adaptive competence consisting of eight factors (interpersonal adaptability - being capable of working with new colleagues, customers, providers; cultural adaptability - being capable of working within different cultural contexts; physical adaptability being capable of working within various and difficult environments; solving of uncertain and unpredictable work situations; etc.). Confronted with these new exigencies, it is obvious that the employees have to be optimistic in what regards their capacity to respond to them, and it is logical that superiors, by renewing their criteria for appreciating the personnel and by integrating the new economic data, would value the subordinates who experience (or state to experience) such a feeling. Our results follow this logic. This being the case, instead of studying the normativity of an object and thus align with a socio-cognitive approach, we could now continue this study by examining the proven level of life satisfaction of the employees, i.e. independently of all research on desirability.

\section{References}

Andrews, F.M., \& Withey, S.B. (1976). Social indicators of well-being: American's perception of life quality. New-York: Plenum. DOI:10.1007/978-1-4684-2253-5

Aziri, B. (2011). Job satisfaction: a literature review. Management Research and Practice, 3 (4), 77-86.

Bouffard, L. (1997). Variations sur le thème du bonheur. Revue Québécoise de Psychologie. 18.3-12.

Buunk, B.P., Collins, R.L., Taylor, S.E., Van Yperen, N.W., \& Dakof, G.A. (1990). The affective consequences of social comparison: Either direction has its ups and downs. Journal of Personality and Social Psychology. 59.1238-1249.

Bradburn, N.M. (1969). The structure of psychological well-being. Chicago: Aldine

Chen, C. (2006). Job satisfaction, organizational commitment and flight attendants turnover intentions: a note. Journal of Air Transport Management, 12 (5), 274-276. doi:10.1016/j.jairtraman.2006.05.001

Cohen, L.H., Towbes, L.C., \& Flocco, R. (1988). Effect of induced mood on self-reported life events and perceived and received social support. Journal of Personality and Social Psychology. 55.669-674.

Diener, E. (1984). Subjective well-being. Psychological Bulletin, 95, 542-575.

Diener, E., Emmons, R. A., Larsen, R. J., \& Griffin, S. (1985). The Satisfaction with Life Scale. Journal of Personality Assessment, 49, 71-75.

Diener, E., Sandvik, W., Pavot, W., \& Gallagher, D. (1991). Response artifacts in the measurement of subjective well-being. Social Indicators Research. 24.35-56.

Diener, E., Suh, E.M., Lucas, R.E., \& Smith, H.L. (1999). Subjective well-being: Three decades of progress. Psychological Bulletin. 125.276-302.

Dubois, N. (1994). La norme d'internalité et le libéralisme. Grenoble : PUG.

Dubois, N. (2005). Normes sociales de valeur et jugement : ancrage sur l'utilité et ancrage sur la désirabilité. Revue Internationale de Psychologie Sociale, 3, 43-80.

Easterlin, R.A. (1995). Will raising the incomes of all increase the happiness of all ? Journal of Economic Behavior and Organization. 27.35-47. 
Fletcher, C., \& Williams, R. (1996). Performance management, job satisfaction and organizational $\begin{array}{llllll}\text { commitment. British Journal of } & \text { Management, } 7 \text { (2), }\end{array}$ doi: 10.1111/j.1467-8551.1996.tb00112.x

Frieswijk, N., Buunk, B.P., Steverink, N., \& Slaets, J.P.J. (2004). The effect of social comparison information on the life satisfaction of frail older persons. Psychology and Aging. 19.183-190.

Gangloff, B. (2008). Normativity of the acceptance of professional injustices via the legislator's paradigm: a study on recruiters. Actes de la $5^{\text {th }}$ International Conference of Applied Psychology (Timisoara, Roumanie, 2007). Timisoara (Roumanie) : Editura Eurobit, 219-228.

Gangloff, B., \& Malleh, N. (2016). French managers and their subordinates'well-being. World Academy of Science, Engineering and Technology. International Journal of Social, Education, Economy, Business and Industrial Engineering, 10(12), 3416-3419.

Gosselin, E. (2005). Contribution à une synthèse des connaissances sur la satisfaction dans la vie: regard psychologique sur une réalité plurielle. Revue de l'Université de Moncton, 36 (2), 131-169. Doi: 10.7202/014502ar

Huebner, E. S. (1991). Initial development of the Student's Life Satisfaction Scale. School Psychology International, Vol 12(3), 231-240.

Javed, M., Balouch, R., \& Hassan, F. (2014). Determinants of job satisfaction and its impact on employee performance and turnover intentions. International Journal of Learning and Development, 4 (2), 120-140. doi: 10.5296/ ijld.v4i2.6094

Jellison, J.M., \& Green, J. (1981). A self-presentation approach to the fundamental attribution error: the norm of internality. Journal of Personality and Social Psychology, 40(4), 643-649.

Lai Wan, H. (2007). Human capital development policies: enhancing employee's satisfaction. Journal of European Industrial Training, 31 (4), 297-322. doi: org/10.1108/03090590710746450

Lent, R.W., Singley, D., Sheu, H.-B., Gainor, K.A., Brenner, B.R., Treistman, D., \& Ades, L. (2005). Social cognitive predictors of domain and life satisfaction: Exploring the theoretical precursors of subjective well-being. Journal of Counseling Psychology. 52.429-442.

Lykken, D., \& Tellegen, A. (1996). Happiness is a stochastic phenomenon. Psychological Science. 7.186-189.

McCrae, R.R., \& Costa, P.T. (1991). Adding liebe und arbeit The full five-factor model and well-being. Personality and Social Psychology Bulletin. 17. 227-232. DOI:10.1177/014616729101700217

Maisonneuve, J. (1973). Introduction à la psychosociologie. Paris: PUF.

Martensen, A. \& Gronholdt, L. (2001). Using employee satisfaction measurement to improve people management: an adaptation of Kano's quality types. Total Quality Management, 12 (7/8), 949-57. doi: 10.1080/09544120100000020

Massé, R. Poulin, C., Dassa, C., Lambert, J., Bélair, S., \& Battaglini, M.A. (1998). Elaboration et validation d'un outil de mesure du bien-être psychologique: l'ÉMMBEP. Revue Canadienne de Santé Publique, 89 (5), 352-357. Doi: http://dx.doi.org/10.17269/cjph.89.1014

Mercier, C., \& Filion, J. (1987). La qualité de vie: perspectives théoriques et empiriques. Santé Mentale au Québec, 12(1), 135-143.

Muchinsky, P. M., \& Morrow, P. C. (1980). A multidisciplinary model of voluntary employee turnover. Journal of Vocational Behavior, 17 (3), 263-290. doi: 10.1016/0001-8791(80)90022-6

Nanda, R., \& Browne, J. J. (1977). Hours of work, job satisfaction and productivity. Public Productivity Review, 2 (3), 46-56. doi: 10.2307/3380223

Oishi, S., Diener, E., Suh, E., \& Lucas, R.E. (1999). Value as a moderator in subjective well-being. Journal of Personality. 67.157-184.

Okun, M.A., Olding, R.W., \& Cohn, C.M.G. (1990). A meta-analysis of subjective well-being interventions among elders. Psychological Bulletin. 108.257-266.

Pelham, B.W., \& Wachsmuth, J.D. (1995). The waxing and waning of the social self: Assimilation and contrast in social comparison. Journal of Personality and Social Psychology. 57.825-838.

Pulakos, E.D., Schmitt, N., Dorsey, D.W., Hedge, J.W., \& Borman, W.C. (2002). Predicting adaptive performance: Further tests of a model of adaptability, Human Performance, 15, 299-323.

Ryan, R.M., \& Deci, E.L. (2000). Self-determination theory and the facilitation of intrinsic motivation, social development, and well-being. American Psychologist. 55.68-78.

Ryff, C., \& Essex, M.J. (1992). The interpretation of life experience and well-being: The sample case of relocation. Psychology and Aging. 7.507-517.

Seligman, M.E.P. (1991). Learned optimism. New York: Random House.

Shin, D.C., \& Johnson, D.M. (1978). Avowed happiness as an overall assessment of the quality of life. Social Indicators Research. 5, 475-492.

Spence, G., Oades, L.G., \& Caputi, P. (2004). Trait emotional intelligence and goal self-integration: Important predictors of emotional well-being. Personality and Individual Differences. 37.449-461.

Vanderberg, R. J., \& Lance, Ch. E. (1992). Examining the causal order of job satisfaction and organizational commitment. Journal of Management, 18 (1), 153-167. doi: 10.1177/014920639201800110

Weiner, B. (1992). Human motivation: Metaphors, theories and research. Newbury Park, California: Sage. 